\title{
Immunohistochemical detection of C-100 hepatitis C virus antigen in formaldehyde-fixed paraffin-embedded liver tissue. Correlation with serum, tissue and in situ RT-PCR results
}

\author{
L. Benkoël, ${ }^{1}$ P. Biagini, ${ }^{2}$ F. Dodero, ${ }^{1}$ X. De Lamballerie, ${ }^{2}$ P. De Micco, ${ }^{2}$ A. Chamlian, ${ }^{1}$ \\ D. Lombardo ${ }^{1}$
}

${ }^{1}$ INSERM U 559, Physiopathologie des Cellules Epithéliales; ${ }^{2}$ Unité des Virus Emergents, Laboratoire de Virologie Moléculaire, Tropicale et Transfusionnelle, Faculté de Médecine, Université de la Méditerranée, Marseille, France

(C)2004, European Journal of Histochemistry

We localized HCV C-100 protein in liver biopsies of 15 patients with chronic hepatitis $\mathrm{C}$ using immunohistochemistry. The results were compared to serum, tissue extract analysis of HCV RNA and in situ RT-PCR described in a previous study. HCV was detected in $80 \%$ of the sera tested, in $40 \%$ of the tissue extracts and in $80 \%$ and $60 \%$ of the tissue sections tested by immunohistochemistry and in situ RTPCR respectively. Compared to the serum positive cases, $83 \%$ and $67 \%$ of the cases were respectively positive with immunohistochemistry and in situ RT-PCR and 41\% were positive with tissue extract detection. Compared to the tissue extract positive cases, $25 \%$ and $50 \%$ of the cases were respectively positive with immunohistochemistry and in situ RT-PCR. Finally, $75 \%$ of the cases positive by immunohistochemistry were also positive by in situ RT-PCR. These results underline the complementarity of the different methods for the precise diagnosis of hepatitis $\mathrm{C}$.

Key words: chronic hepatitis C, immunohistochemistry, C-100 protein, hepatitis C virus RNA, in situ RT-PCR.

Correspondence: L. Benkoël, INSERM U 559,

Physiopathologie des Cellules Epithéliales, Faculté de Médecine, 27, boulevard Jean Moulin, 13385 Marseille Cedex 05, France.

Phone: international +33.4 .91324400 .

Fax: international +33.4 .91830187 .

E-mail: liliane.benkoel@medecine.univ-mrs.fr

Paper accepted on January 8, 2004

European Journal of Histochemistry 2004; vol. 48 issue 2 [Apr-Jun]: 185-190
S everal studies based on the detection of hepatitis $\mathrm{C}$ virus ( $\mathrm{HCV}$ ) RNA or virus-related proteins in formaldehyde-fixed paraffin-embedded liver biopsies have been already reported. These studies used reverse transcriptase-polymerase chain reaction ( $R T-P C R$ ) performed on extracted RNA (Guerrero et al., 1997; Svoboda-Newman et al., 1997; Dries et al., 1999; Soguero et al., 2000), in situ hybridization (Haruna et al., 1993; Nouri-Aria et al., 1993; Tang et al., 1995; Cho et al., 1996; Felgar et al., 1996; Kojima et al., 1996; Sansonno et al., 1996; Sansonno et al., 1997; Ohishi et al., 1999; Chang et al., 2000; Rodriguez-Inigo et al., 2000), in situ RT-PCR (Lidonnici et al., 1995; Nuovo, 1998; Walker et al., 1998; Biagini et al., 2001) and immunohistochemistry (IMH) (Gonzalez-Peralta et al., 1994; Komminoth et al., 1994; Chamlian et al., 1996; Vartanian et al., 1996; Kawamura et al., 1997; Moriya et al., 1997; Muramarsu et al., 1997; Brody et al., 1998; Yasui et al., 1998; Errington et al., 1999; Gomez et al., 1999; Kim et al., 1999; Nakopoulo et al., 1999; Nayak and Sathar, 1999; Wölk et al., 2000). Analysis of the corresponding data concerning the intracellular localization of HCV RNA and proteins revealed controversial results. Most studies located HCV constituents in cytoplasm of hepatocytes (Gonzalez-Peralta et al., 1994; Komminoth et al., 1994; Tang et al., 1995; Sansonno et al., 1996; Vartanian et al., 1996; Sansonno et al., 1997; Bettinger et al., 1999; Nakopoulo et al., 1999; Ohishi et al., 1999; Chang et al., 2000; RodriguezInigo et al., 2000; Wölk et al., 2000) whereas some other works described a cytoplasmic and/or nuclear localization (Haruna et al., 1993; Nouri-Aria et al., 1993; Lidonnici et al., 1995; Chamlian et al., 1996; Cho et al., 1996; Felgar et al., 1996; Kawamura et al., 1997; Morimoto et al., 1997; Moriya et al., 1997; Brody et al., 1998; Walker et al., 1998; Errington et al., 1999; Kim et al., 1999; Nayak and 
Table 1. Comparison of immunohistochemical results, HCV-RNA detection by RT-PCR, histological parameters and biological markers.

\begin{tabular}{|c|c|c|c|c|c|c|c|c|}
\hline \multirow[b]{2}{*}{ Cases } & \multirow[b]{2}{*}{ Knodell score ${ }^{1}$} & \multirow[b]{2}{*}{$A L T^{2}(I U / L)^{1}$} & \multirow[b]{2}{*}{ HCV serology ${ }^{1}$} & \multirow[b]{2}{*}{ Seric HCV RNA ${ }^{1}$} & \multirow[b]{2}{*}{$\begin{array}{l}\text { Liver tissue } \\
\text { extract }^{1}\end{array}$} & \multirow[b]{2}{*}{$\begin{array}{c}\text { In situ } \\
\text { staining }\end{array}$} & \multicolumn{2}{|c|}{ Immunohistochemistry } \\
\hline & & & & & & & $\begin{array}{l}\text { Nuclear } \\
\text { Staining }\end{array}$ & $\begin{array}{l}\text { Cytoplasmic } \\
\text { staining }^{3}\end{array}$ \\
\hline 1 & 10 & 12 & + & + & + & 0 & 0 & 0 \\
\hline 2 & 8 & 12 & + & + & - & 3 & 0 & 3 \\
\hline 3 & 5 & 15 & + & + & + & 1 & 0 & 3 \\
\hline 4 & 7 & 150 & + & + & + & 0 & 0 & 0 \\
\hline 5 & 13 & 26 & + & + & + & 3 & 4 & 0 \\
\hline 6 & 10 & 36 & + & + & - & 0 & 0 & 4 \\
\hline 7 & 5 & 22 & + & - & - & 0 & 1 & 4 \\
\hline 8 & 11 & 18 & + & + & - & 2 & 0 & 4 \\
\hline 9 & 14 & 25 & + & + & - & 2 & 1 & 0 \\
\hline 10 & 10 & 22 & + & + & - & 2 & 2 & 0 \\
\hline 11 & 5 & 16 & + & - & + & 0 & 0 & 0 \\
\hline 12 & 13 & 11 & + & - & - & 1 & 1 & 0 \\
\hline 13 & 12 & 14 & + & + & + & 2 & 0 & 4 \\
\hline 14 & 5 & 11 & + & + & - & 0 & 0 & 3 \\
\hline 15 & 5 & 18 & + & + & - & 3 & 3 & 0 \\
\hline
\end{tabular}

${ }^{1}$ according to Biagini et al., (2001); ${ }^{2}$ ALT: alanine transaminase; ${ }^{3}$ the number of stained cells was expressed semi-quantitatively as 0: no staining, $1: 1$ to $10 \%$ of the stained cells, 2: 10 to $30 \%, 3$ : 30 to $40 \%$ and 4 : more than $40 \%$.

Sathar, 1999). Furthermore, no significant correlation between diagnosis, in situ detection of viral RNA and immunohistochemical results has been frequently described (Kojima et al., 1996; Vartanian et al., 1996; Negro and Hadengue, 1997; Scheuer et al., 1997; Dries et al., 1999; Gomez et al., 1999; Biagini et al., 2001). In addition, conflicting results on the correlation between serum and hepatic HCV RNA detected in tissue extracts or in situ RT-PCR and IMH have been underlined (Gonzalez-Peralta et al., 1994; Lidonnici et al., 1995; Gomez et al., 1999). Different sensitivities in detecting HCV in paraffin-embedded and in formaldehyde-fixed tissues have been described by several authors (Blight et al., 1992; Tsutsumi et al., 1994; Guerrero et al., 1997). This could be not only due to the fixation processes but also to some denaturation occuring during storage of liver biopsies (Akyol et al., 1992) and/or to the low level of HCV components and their heterogeneous distribution in liver tissue.

On the other hand, controversial results concerning the specificity of immunohistochemical methods applied on paraffin sections of formaldehyde-fixed liver biopsies have been related. Some authors described unreliable immunohistochemical results (Komminoth et al., 1994; Vartanian et al., 1996; Svoboda-Newman et al., 1997; Gomez et al., 1999), while others confirmed the specificity and sensitivity of their immunohistochemical methods for detection of HCV in fixed liver tissue (Brody et al., 1998).
Therefore, the aim of this study was first to perform HCV immunohistochemical detection in patients with histologic diagnosis of chronic hepatitis $C$, and subsequently to compare these results to previous findings related to HCV RNA detection approaches (Biagini et al., 2001).

\section{Materials and Methods}

\section{Materials}

15 cases of chronic hepatitis $\mathrm{C}$ positive for HCV serology (third generation Elisa tests) studied in a previous work (Biagini et al., 2001) were selected (Table 1). Liver biopsies were fixed for $4 \mathrm{~h}$ in $4 \%$ buffered formalin solution, routinely embedded in paraffin and cut into $5 \mu \mathrm{m}$ serial sections.

\section{Immunohistochemistry}

A monoclonal antibody anti-C100-3 non-structural protein (clone TORDJI 22, Clonatec-Biosoft, France) was used and two immunohistochemical detection methods were tested: alkaline phosphatase (AP) detection (EnVision kit from Dako, France) and immunogold silver staining (IGSS), which was previously described (Chamlian et al., 1996).

The list of reagents and sources used in this study is given in Table 2. Sections were treated with primary antibody 1:100 diluted in antibody diluent (Dako), during $50 \mathrm{~min}$ at room temperature (AP method) or during $2 \mathrm{~h}$ at $37^{\circ} \mathrm{C}$ (IGSS method), with secondary antibody for $10 \mathrm{~min}$ at room temperature 
Table 2. Reagents and sources.

\begin{tabular}{|c|c|c|c|}
\hline Procedure & Primary Antibody & Secondary Antibody & Staining Technique \\
\hline AP* & $\begin{array}{l}\text { Mouse monoclonal IgG1 to HCV C100-3, } \\
\text { clone TORDJI-22 } \\
\text { (217-91, Clonatec-Biosoft, France) }\end{array}$ & $\begin{array}{l}\text { Alkaline phosphatase labelled polymer conjugated } \\
\text { to goat anti-mouse lgG } \\
\text { (EnVision system, K 1396, Dako, France) }\end{array}$ & $\begin{array}{c}\text { Fast red, levamisole } \\
\text { (EnVision system, K 1396, Dako, France) }\end{array}$ \\
\hline IGSS** & $\begin{array}{l}\text { Mouse monoclonal IgG1 to HCV C100-3, clone TORDJI-22 } \\
\text { (217-91, Clonatec-Biosoft, France) }\end{array}$ & $\begin{array}{l}\text { Goat gold-labelled antimousse lgG } \\
\text { (RPN 451, Auroprobe, LM,Amersham Biosciences, France) }\end{array}$ & $\begin{array}{c}\text { Silver enhancement } \\
\text { (RPN 491, intenSE M, Amersham Biosciences, France) }\end{array}$ \\
\hline
\end{tabular}

(AP method) or 1:40 diluted in Dako antibody diluent during $\mathrm{l} h$ at room temperature (IGSS method). The final staining procedure was Fast Red with levamisole for $4 \mathrm{~min}$ at room temperature (AP method) and silver enhancement for $14 \mathrm{~min}$ at $23^{\circ} \mathrm{C}$ (IGSS method). Slides were washed in PBS or TBS (AP procedure) and in distilled water after this final step and counterstained in Mayer's hemalum solution. They were then mounted in aqueous permanent mounting medium after AP procedure or dehydrated and mounted in synthetic resin (IGSS method).

Two controls were performed:

(i) Omission of the first step of immunohistochemical procedures (incubation without primary antibody).

(ii) Use of a non-immune mouse serum 1:100 diluted in Dako antibody diluent instead of primary monoclonal antibodies.

The number of stained cells was expressed semiquantitatively as 0 : no staining, 1: 1 to $10 \%$ of the stained cells, 2: 10 to $30 \%, 3: 30$ to $40 \%$ and 4 : more than $40 \%$.

\section{Statistical analysis}

Statistical analyses were performed using the Statcalc module of the Epi Info program (Version 6, CDC, Atlanta GA). Frequency distributions were compared using the chi-square $\left(\chi^{2}\right)$ test (MantelHaenszel and Yates analysis) and the Fischer exact test.

The relationships between immunohistochemical staining and in situ HCV RNA detection, biological markers (serum and tissue extract HCV RNA status, alanine amino transferase levels), and clinical data (Knodell score) were analyzed.

\section{Results}

Table 1 summarized immunohistochemical results and previous data on HCV RNA detection by RTPCR in sera, tissue extract and by in situ RT-PCR.

\section{Immunohistochemistry}

The C100-3 antigen was mainly located in hepatocytes (Table 1). With AP detection method, nuclei were stained (Figure $1 \mathrm{a}$ ) and coarse clumped granular staining was found in cytoplasm of some hepatocytes (Figure 1b). The stained cells were isolated or clustered. To a lesser extend, nuclei of Kupffer, bile duct and mononuclear cells were also stained. The staining pattern was similar with IGSS method. However, IGSS gave a stronger reaction than AP as shown in Figure $1 d$,e. No staining was found in control slides (Figure 1c, f).

Nuclear and/or cytoplasmic labeling was found in $80 \%$ of the cases. Among them, 6 cases showed a cytoplasmic staining and 5 a nuclear one. Only one case (case 7) exhibited both cytoplasmic and nuclear reactions. $75 \%$ of the cases positive by $\mathrm{IMH}$ were also positive by in situ RT-PCR detection. In $20 \%$ of the cases, both IM H and in situ RT-PCR showed negative results. In addition, 3 cases were only detectable by IMH. Finally, compared to the cases positive by RT-PCR in serum and to the cases positive by RT-PCR on tissue extracts, $83 \%$ and $25 \%$ of the cases were respectively positive using IMH.

\section{Statistical analysis}

Statistical analysis did not show significant relationship between immunohistochemical or in situ RT-PCR stainings and serum, tissue extract HCV 

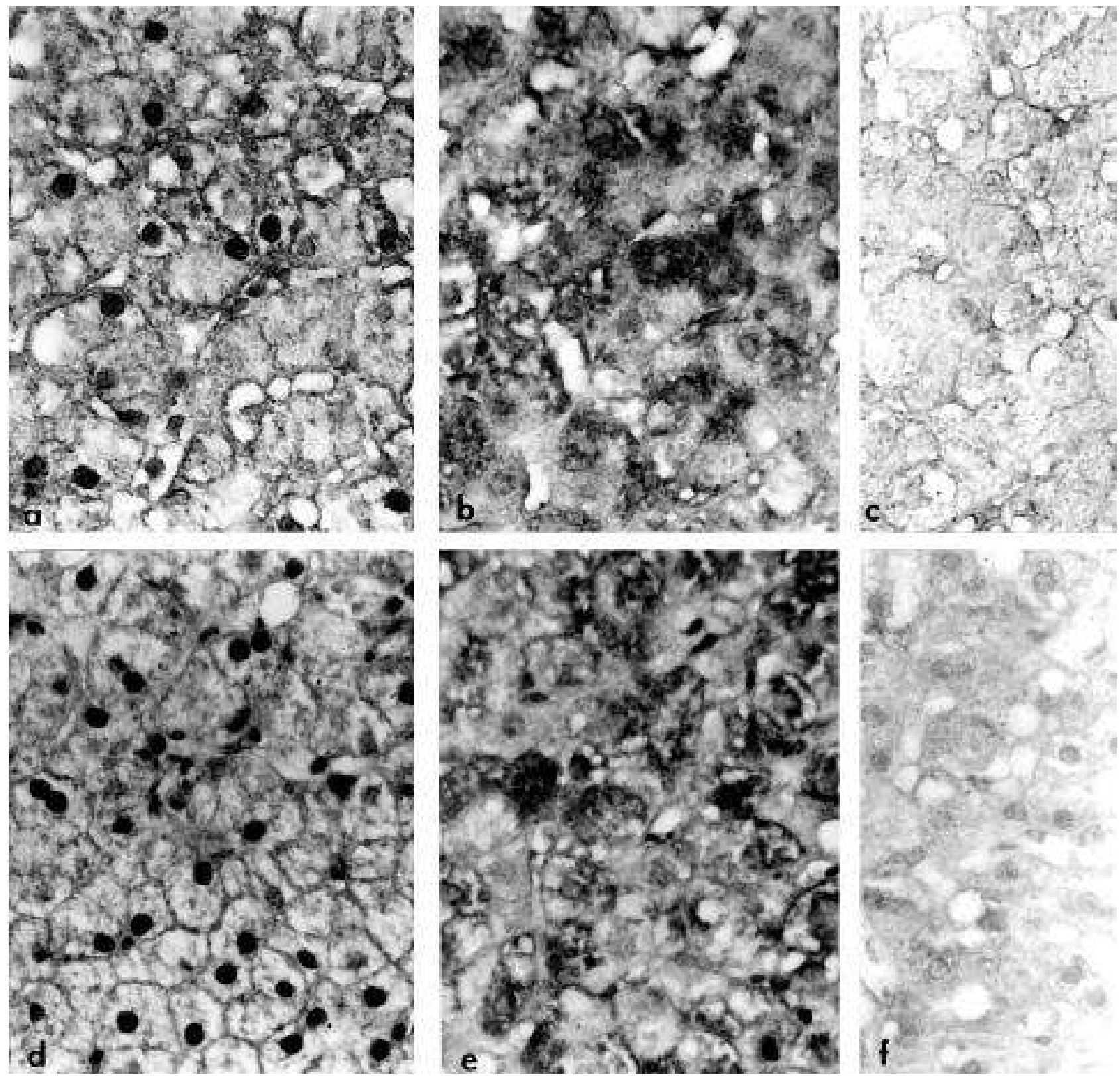

Figure 1. Liver sections from patients with chronic hepatitis C. Immunohistochemical staining of HCV C100-3 non-structural protein (magnification, x450). (a-c) Alkaline phosphatase detection (AP). (a) nuclear staining in a cluster of hepatocytes. (b) Granular cytoplasmic staining in some hepatocytes. (c) No staining in control section using non-immune mouse serum as primary antibodies. (d-f) Immunogold silver staining (IGSS). (d) Strong nuclear staining in hepatocytes. (e) Granular cytoplasmic staining in clustered hepatocytes. (f) No staining in control section using non-immune mouse serum as primary antibodies.

RNA status (positive/negative), ALT levels and Knodell scores.

\section{Discussion}

In a previous paper, (Biagini et al., 2001), we emphasize the lack of clear correlation between HCV RNA molecular detection methods in biologic samples of patients with chronic hepatitis $C$, thus confirming the literature data (Akyol et al., 1992; Bresters et al., 1994; Negro and Hadengue, 1997; Scheuer et al., 1997; Dries et al., 1999; Chang et al., 2000). Moreover, our findings based on in situ RT-PCR approach revealed a nuclear detection of HCV RNA as previously described by several authors (Haruna et al., 1993; Nouri-Aria et al., 1993; Cho et al., 1996; Walker et al., 1998), but in discrepancy with others studies showing a cytoplas- 
mic localization (Tanaka et al., 1993; Tang et al., 1995; Kojima et al., 1996; Lau et al., 1996; Sansonno et al., 1996; Sansonno et al., 1997; Bettinger et al., 1999; Ohishi et al., 1999; Chang et al., 2000; Rodriguez-Inigo et al., 2000).

In this study, the immunolocalization of the $\mathrm{Cl00}$ 3 non-structural protein of HCV was mainly found in cytoplasm and nuclei of hepatocytes. In addition, in most of the cases, hepatocytes with cytoplasmic staining were devoid of nuclear staining and inversely. These different localizations were also described in the literature which attributed cytoplasmic or nuclear, or cytoplasmic and nuclear localization to HCV structural and non-structural proteins (Gonzalez-Peralta et al., 1994; ; Komminoth et al., 1994; Vartanian et al., 1996; Ishido et al., 1997; Kawamura et al., 1997; Moriya et al., 1997; Muramatsu et al., 1997; Brody et al., 1998; Yasui et al., 1998; Errington et al., 1999; Gomez et al., 1999; Honda et al., 1999; Kim et al., 1999; Nakopoulo et al., 1999; Nayak and Sathar, 1999; Wölk et al., 2000).

Immunohistochemical results showed here a good correlation between in situ RT-PCR method and IMH (75\% of cases in situ RT-PCR positive were also positive with IMH). Moreover, three cases negative by the in situ RT-PCR approach were positive with immunohistochemical detection. These results indicate that IMH seems a sensitive method to detect HCV using the TORDJI-22 monoclonal antibody. Finally, statistical analysis did not show significant relationship between the different biological parameters, in particular between high or low Knodell scores and in situ RT-PCR staining (Biagini et al., 2001) or immunodetection.

In conclusion, our results show that the methods described here are complementary for HCV detection. The presence of HCV protein in the nuclei of hepatocytes in patients with chronic hepatitis $\mathrm{C}$ may play a role in the persistence of HCV infection (Errington et al., 1999), whereas the detection of HCV RNA in hepatocytes nuclei could also suggest that HCV, as other members of the Flaviviridae family, may have a nuclear replicative phase (Westaway, 1987).

\section{References}

Akyol G, Dash S, Shieh YSC, Malter JS, Gerber MA. Detection of hepatitis $C$ virus RNA sequences by polymerase chain reaction in fixed liver tissue. Mod Pathol 1992;5:501-4.

Bettinger, D, Mougin C, Fouque B, Kantelip B, Miguet JP, Lab M. Direct in situ reverse transcriptase-linked polymerase chain reaction with biotinylated primers for the detection of hepatitis $C$ virus RNA in liver biopsies. J Clin Virol 1999;12:233-41.

Biagini P, Benkoël L, Dodero F, De Lamballerie X, Chamlian V, Nouhou $\mathrm{H}$, et al. Hepatitis $\mathrm{C}$ virus RNA detection by in situ RT-PCR in formalin-fixed paraffin-embedded liver tissue. Comparison with serum and tissue results. Cell Mol Biol 2001;47:167-71.

Blight K, Trowbridge R, Rowland R, Gowans E. Detection of hepatitis C virus RNA by in situ hybridization. Liver 1992;12:289-99.

Bresters D, Schipper MEI, Reesink HW, Boeser-Nunnink BDM, Cuypers HTM. The duration of fixation influences the yield of HCV CDNAPCR products from formalin-fixed paraffin-embedded liver tissue. J Virol Methods 1994;48:267-72.

Brody RI, Eng S, Melamed J, Mizrachi H, Schneider RJ, Tobias H, et al. Immunohistochemical detection of hepatitis $C$ antigen by monoclonal antibody TORDJI-22 compared with PCR viral detection. Am J Clin Pathol 1998;110:32-7.

Chamlian A, Benkoël L, Sahel J, Cherid A, Brisse J, Ikoli JF, et al. Immunohistochemical detection of hepatitis $C$ virus related $\mathrm{C} 100-3$ and core antigens in formalin-fixed liver tissue. Cell Mol Biol 1996; 42:557-66.

Chang M, Marquardt AP, Wood BL, Williams 0 , Cotler SJ, Taylor SL, et al. in situ distribution of hepatitis $C$ virus replicative-intermediate RNA in hepatic tissue and its correlation with liver disease. J Virol 2000;74:944-55.

Cho SW, Hwang SG, Han DC, Jin SY, Lee MS, Shim CS, et al. in situ detection of hepatitis $C$ virus RNA in liver tissue using a digoxigeninlabeled probe created during a polymerase chain reaction. $J$ Med Virol 1996;48:227-33.

Dries V, von Both I, Muller M, Gerken G, Schirmacher P, Odenthal M, et al. Detection of hepatitis $C$ virus in paraffin-embedded liver biopsies of patients negative for viral RNA in serum. Hepatology 1999;29:223-9.

Errington W, Wardell AD, McDonald S, Goldin RD, McGarvey MJ. Subcellular localisation of NS3 in HCV-infected hepatocytes. J Med Virol 1999;59:456-62.

Felgar RE, Montone KT, Furth EE. A rapid method for the detection of hepatitis C virus RNA by in situ hybridization. Mod Pathol $1996 ; 9: 696-702$.

Gomez JA, Aardema K, Gown AM, Nakhleh RE. Utility of available hepatitis C virus (HCV) antibodies TORDJI-22 and HCV-88: evaluation of allograft reinfection and correlation with PCR quantitation. Pathol Int 1999;49:162A.

Gonzalez-Peralta RP, Fang JWS, Davis GL, Gish R, Tsukiyama-Kohara $\mathrm{K}$, Kohara $\mathrm{M}$, et al. Optimization for the detection of hepatitis $\mathrm{C}$ virus antigens in the liver. J Hepatol 1994;20:143-7.

Guerrero RB, Batts KP, Brandhagen DJ, Germer JJ, Perez RG, Persing $\mathrm{DH}$. Effects of formalin fixation and prolonged block storage on detection of hepatitis $C$ virus RNA in liver tissue. Diagn Mol Pathol, 1997;6:277-81.

Haruna $Y$, Hayashi N, Hiramatsu N, Takehara T, Hagiwara H, Sasaki $Y$, et al. Detection of hepatitis $C$ virus RNA in liver tissues by an in situ hybridization technique. J Hepatol 1993;18:96-100.

Honda A, Arai Y, Hirota N, Sato T, Ikegaki J, Koizumi T, et al. Hepatitis $C$ virus structural proteins induce liver cell injury in transgenic mice. J. Med Virol 1999;59:281-9.

Ishido S, Muramatsu S, Fujita T, Iwanaga Y, Tong WY, Katayama $Y$, et al. Wild-type, but not mutant-type, p53 enhances nuclear accumulation of the NS3 protein of hepatitis C virus. Biochem Biophys Res Com 1997:230:431-6.

Kawamura T, Furusaka A, Koziel MJ, Chung RT, Wang TC, Schmidt EV, et al. Transgenic expression of hepatitis $C$ virus structural protein in the mouse. Hepatology 1997;95:1014-21.

Kim JE, Song WK, Chung KM, Bach SH, Jang SK. Subcellular localization of hepatitis $C$ viral proteins in mammalian cells. Arch Virol 1999; 144:329-43.

Kojima S, Tanaka Y, Enomoto N, Marumo F, Sato C. Distribution of hepatitis $C$ virus RNA in the liver and its relation to histopathological changes. Liver 1996;16:55-60.

Komminoth $\mathrm{P}$, Adams $\mathrm{V}$, Long AA, Roth J, Saremaslani $\mathrm{P}$, Flury $\mathrm{R}$, et al. Evaluation of methods for hepatitis $C$ virus detection in archival liver biopsies. Comparison of histology, immunohistochemistry, insitu hybridization, reverse transcriptase polymerase chain reaction (RT-PCR) and in-situ RT-PCR. Pathol Res Pract 1994;190:101725.

Lau GK, Davis GL, Wu SP, Gish RG, Balart LA, Lau JYN. Hepatic 
expression of hepatitis $C$ virus RNA in chronic hepatitis $C$ : a study by in situ reverse-transcription polymerase chain reaction. Hepatology 1996;23:1318-23.

Lidonnici K, Lane B, Nuovo GJ. Comparison of serologic analysis and in situ localization of PCR-amplified cDNA for the diagnosis of hepatitis C infection. Diagn Mol Pathol 1995;4:98-107.

Morimoto H, Kuroki T, Kobayashi K, Nomura S, Sakurai M. A histopathological study on localization of hepatitis $C$ virus RNA in liver of chronic hepatitis C. Osaka Med J 1997:43:153-71.

Moriya K, Fujie H, Yotsuyanagi H, Shintani $Y$, Tsutsumi T, Matsuura Y, et al. Subcellular localization of hepatitis $C$ virus structural proteins in the liver of transgenic mice. Jpn J Med Sci Biol 1997;50:169-77.

Muramatsu S, Ishido S, Fujita T, Itoh M, Hotta H. Nuclear localization of the NS3 protein of hepatitis $C$ virus and factors affecting the localization. J Virol 1997;71:4954-61.

Nakopoulo L, Manolaki N, Lazaris AC, Kostaridou S, Gakiopoulou H, Davaris $P$, Kattamis C. Tissue immunodetection of c100 hepatitis C virus antigen in major thalassemic patients. Hepato-gastroenterology 1999; 46:2515-2520.

Nayak NC, Sathar SA. Immunohistochemical detection of hepatitis C virus antigen in paraffin embedded liver biopsies from patients with chronic liver disease. Acta Histochem, 1999; 101: 409-19.

Negro, $F$, and Hadengue, A. Détection de I'ARN du virus de I'hépatite C par hybridation in situ: une analyse critique. Gastroenterol Clin Biol 1997; 21:93-7.

Nouri-Aria KT, Sallie R, Sangar D, Graeme JMA, Smith H, Byrne J, Portmann B, Eddleston ALWF, Williams R. Detection of genomic and intermediate replicative strands of hepatitis $C$ virus in liver tissue by in situ hybridization. J Clin Invest 1993; 91:2226-34.

Nuovo GJ. Histologic distribution of hepatitis A, B, C, D, E, and G with concomitant cytokine response in liver tissue. Diagn Mol Pathol 1998; 7:267-75.

Ohishi, M, Sakisaka, S, Harada, M, Koga, E, Taniguchi, E, Kawaguchi, T, Sasatomi, K, Sata, M, Kurohiji, T, Tanikawa, K. Detection of hepatitis $C$ virus and hepatitis $C$ virus replication in hepatocellular carcinoma by in situ hybridization. Scand J Gastroenterol 1999; 34: 4328.

Rodriguez-Inigo E, Casqueiro M, Navas S, Bartolomé J, Pardo M, Carreno V. Fluorescent "in situ" hybridization of hepatitis C virus RNA in peripheral blood mononuclear cells from patients with chronic hepatitis C. J. Med Virol 2000; 60:269-74.

Sansonno D, Iacobelli AR, Cornacchiulo V, Iodice G, Dammacco F. Detection of hepatitis $C$ virus ( $\mathrm{HCV}$ ) proteins by immunofluorescence and HCV RNA genomic sequences by non-isotopic in situ hybridization in bone marrow and peripheral blood mononuclear cells of chronically HCV-infected patients. Clin Exp Immunol 1996; 103:414-21.

Sansonno, D, Cornacchiulo, V, Racanelli, V, and Dammacco, F. in situ simultaneous detection of hepatitis C virus RNA and hepatitis C virus-related antigens in hepatocellular carcinoma. Cancer 1997; 80:22-33.

Scheuer PJ, Krawczynski K, Dhillon AP. Histopathology and detection of hepatitis C virus in liver. Springer Semin Immunopathol 1997; 19:27-45.

Soguero C, Campo E, Ribalta T, Sanchez-Tapias J M, Saiz JC, Bruguera M. Assessment of genotype and molecular evolution of hepatitis $C$ virus in formalin-fixed paraffin-embedded liver tissue from patients with chronic hepatitis C virus infection. Lab Invest 2000; 80:851856.

Svoboda-Newman SM, Greenson JK, Singleton TP, Sun R, Frank T. Detection of hepatitis C by RT-PCR in formalin-fixed paraffinembedded tissue from liver transplant patients. Diagn Mol Pathol 1997, 6:123-9.

Tanaka Y, Enomoto N, Kojima S, Tang L, Goto M, Marumo F, Sato C. Detection of hepatitis $C$ virus RNA in the liver by in situ hybridization. Liver 1993; 13:203-8.

Tang L, Tanaka Y, Enomoto N, Marumo F, Sato C. Detection of hepatitis $C$ virus RNA in hepatocellular carcinoma by in situ hybridization. Cancer 1995; 76:2211-6.

Tsutsumi M, Urashima S, Takada A, Date T, Tanaka Y. Detection of antigens related to hepatitis $C$ virus RNA encoding the NS5 region in the livers of patients with chronic type C hepatitis. Hepatology 1994; 19:265-72.

Vartanian RK, Dupuis B, Rock N, Anderson FH, Owen DA. Non specificity of the novel paraffin-reactive hepatitis $C$ virus monoclonal antibody, clone TORDJI-22. Lab Invest 1996; 74:138A.

Walker FM, Dazza MC, Dauge MC, Boucher 0, Bedel C, Henin D, et al. Detection and localization by in situ molecular biology techniques and immunohistochemistry of hepatitis $C$ virus in livers of chronically infected patients. J Histochem Cytochem 1998;46:653-60.

Westaway EG. Flaviviruses replication strategy. Adv Vir Res 1987; 33: 45-90.

Wölk B, Sansonno D, Kräusslich HG, Dammacco F, Rice CM, Blum HE, et al. Subcellular localization stability and trans-cleavage competence of the hepatitis C virus NS3-NS4 complex expressed in tetracycline-regulated cell lines. J Virol 2000;4:2293-304.

Yasui K, Wakita T, Tsukiyama-Kohara K, Funahashi SI, Ichikawa M, Kajita T, et al. The native form and maturation process of hepatitis C virus core protein. J Virol 1998;72:6048-55. 